\title{
Cultural innovative enterprises: not just philantrophy
}

\section{Silvia Guizzardi ${ }^{1}$}

Published online: 2 September 2020

(c) The Author(s) 2020

\begin{abstract}
This paper is focused on the "cultural innovative enterprises", introduced into italian law by Decree Law 179/2012 on "Further urgent measures for Italy's economic growth", converted into Law 221/2012. It is about new innovative enterprises that deal to develop, manufacture and distribuite innovative goods and services of high technological value, operating exclusively in the fields of cultural heritage promotion and cultural services provision. These companies can contribute to reduce the Italian youth employment emergency thanks on one hand to the reduced entry barriers related to the technology developments needed to "begin doing business" and on the other hand to the widespread territorial distribution of the italian cultural heritage to which services and processes will be applied. Furthermore, the increase of the GDP in regions undergoing a state of economic difficulty is a goal at hand. From a more general point of view, the cultural innovative start ups are an important element in stimulating new forms of collaboration between public entities responsible for the protection of the artistic heritage and private companies involved in its promotion. This type of partnership can contribute to the promotion and dissemination of new essential skills within the public administration aimed at a virtuous evolution of the way the overall economic system works.
\end{abstract}

Keywords Cultural innovative enterprises $\cdot$ Start up · Artistic heritage $\cdot$ Cultural heritage

\section{Introduction}

Italy is one of the countries with the highest concentration of cultural and artistic goods: monuments, archaeological and historical sites, museums. An artistic and monumental heritage often difficult to value in economic terms and the protection of which is a cost that in times of economic crisis and spending cuts the state

Silvia Guizzardi

silvia.guizzardi@unibo.it

1 Department of Legal Studies, Alma Mater Studiorum University of Bologna, Via Zamboni 29, 40126 Bologna, Italy 
unwillingly finds hitself having to resize. ${ }^{1}$ The cultural heritage sector has undoubtedly great importance in a country like Italy, which has a vast wealth of goods that fall into that category. It may, indeed, be regarded as a key sector for our country, with a strong impact on other related sectors, such as tourism.

Yet, as demonstrated by numerous international examples where the artistic and monumental heritage is certainly not comparable to the Italian one, not only is it exploitable from an economic standpoint, but it can also act as a driving force for economic and social development.

In this context, without prejudice to more traditional incentives of public and private development of the artistic and cultural heritage, I consider it important to dwell on the role that can be played by the so called "cultural innovative enterprises", recently introduced into our law by Decree Law 179/2012 on "Further urgent measures for Italy's economic growth", converted into Law 221/2012.

It comes to new innovative enterprises (so called start ups) that deal to develop, produce and commercialize innovative goods and services of high technological value, operating exclusively in the areas of cultural heritage promotion and cultural services provision. They are counted according to special legislation among innovative start-ups with a social goal, ${ }^{3}$ because in addition to being profit-oriented enterprises that respond to market demand, ${ }^{4}$ they are also moved by the need to satisfy interests of a general nature, generating a multitude of positive effects, direct and indirect, on the quality of life of citizens and on economic and social growth of the country.

With the introduction of the cultural innovative start up we have in primis an opportunity to create innovative goods, services and processes of high technological value that can allow new ways of use, preservation and promotion of the artistic and cultural heritage and provision of cultural services. At the same time, these companies can positively impact throughout the Italian territory on the Italian youth employment emergency thanks on one hand to the reduced entry barriers related to the technology developments needed to "begin doing business" and on the other hand to the widespread distribution of the cultural heritage to which services and

\footnotetext{
${ }^{1}$ Too often, political choices have affected the cultural heritage, to the benefit of the destination of public funding to other sectors of the economy, with the greatest impact on the electorate. For that reason and for others, such as the increasing organizational and managerial difficulties in the field of public administration, public intervention has proved insufficient.

2 Decree Law n.179 of 18 October 2012 ("Decreto Crescita-bis") converted with amendments into Law no. 221 of 17 December 2012, introduced into our legislation provisions regulating the formation and development of "innovative start-up companies", with a view to promoting sustainable growth, technological development, new business ideas and employment, furthering social mobility and attracting foreign talents, innovative enterprises and capital to Italy.

${ }^{3}$ Start-ups with social goals are also innovative start ups. Which must meet all the requirements of the innovative start ups and must operete in sopecific areas as well as the social enterpricses: social work, health care and social care, education and training, enviromental protection, promotion of cultural heritage, social turism, undergraduate and post graduate edication, cultural services, non accademic training, services for the social enterprises of entities of which 70 per cent is composed of social enterprises.

${ }^{4}$ All the innovative start ups must not have distributed profits since their incorporation year nor must they distribute any while the beneficial regime is in place. The prohibition regards not only innovative start ups with social goals and it gameet the requirements of guaranteeing the alla the profits will be invested in the start ups activitity.
} 
processes will be applied. Furthermore, an additional positive effect is the one on the GDP of regions undergoing a state of economic difficulty.

In the end, and from a more general point of view, the cultural innovative start ups are an important element in stimulating new forms of collaboration between public entities responsible for the protection of the artistic heritage and private companies involved in its promotion. This type of partnership can contribute to the promotion and dissemination of new essential skills within the public administration aimed at a virtuous evolution of the way the overall economic system works. ${ }^{5}$

With the purpose to create favourable conditions to the establishment and the development of cultural innovative start ups, the Italian lawmakers improved and broadened a range of measures which involve a series of relevant temporary exemptions from common law, aimed at reducing costs, particularly those arising from employment and taxes, ${ }^{6}$ designed to support fund raising (equity and bank loans) and spread over time the debt-related risks, as well as properly frame the possibility of bankruptcy, given the higher than average chance of it happening for highly innovative companies with a significant enterpreneurial risk. ${ }^{7}$ The start up legislation is a composite discipline that acts on multiple levels (corporate, tax, labor and bankruptcy), following a so called systemic approach.

\section{The cultural innovative start ups}

As above mentioned, the cultural innovative start ups are new enterprises of high technological value with social goals that produce, develop and commercialize innovative goods and services of high technological value, operating in specific domains: cultural heritage promotion and cultural services provision.

Before going to the details of what requirements are to be laid down to benefit from the favourable discipline, it is important to make it clear that the cultural innovative start up is not a new type of company, but rather a qualification which may concern any type of company which, in addition to submitting all the specific requirements as identified by the law, adopts an organization model that may

\footnotetext{
${ }^{5}$ Investments in the cultural heritage sector, although do not give noticeable results in the short, but rather in the medium term, produce positive effects on the entire chain linked to that heritage. First, it increases the territorial attractiveness in terms of tourism promotion that is derived from innovation in the offer of cultural services or from the possibility to increase to activily combact the decay of historical and artistic heritage thanks to new technologies that reduce costs and expand the means of intervention. In addition to these investments benefit he publishing industry, graphics and multimedia, publishing catalogs, guides, reproductions, videos, souvenirs, handicrafts, service companies and multimedia installations, etc.

6 Article 29 of Decree Law no.179/2012 introduced also a tax incentive for entities which invest directly or indirectly (through collective investment undertakings or other companies) in the capital of innovative start-up companies, consisting in a reduction of the income tax liability as a percentage of the investment made.

7 Maltoni -Spada, L'impresa start up innovativa costituita in società a responsabilità limitata, in www. cavererespondere.it, 2013, p. 1 and in Riv. Not., 2013, 1113 e ss.
} 
guarantee a limited liability to owners. This is especially relevant in case of bankrupcy, so that the owners' personal assets will not be affected. ${ }^{8}$

In accordance of Article 25, paragraph 2 of D.L. 179/2012, indeed, the cultural innovative start up may be incorporated in the form of joint-stock company (società per azioni), limited liability company (società a responsabilità limitata), limited partnership (società in accomandita per azioni), cooperative company (società cooperativa) and Italian-resident Societas Europaea. Ministerial Decree 30 June 2014 includes non-resident companies among innovative start-up companies, provided that they are resident in EU or EEA Member States, carry out a business through a $\mathrm{PE}$ and meet the requirements for resident companies.

However, it should be stated that five years after the introduction of the special legislation about innovative start ups, approximately $80 \%$ of these enterprises chose the form of limited liability company (also s.r.l.).

The limited liability company therefore became the chosen entity for the performance of innovative activities of high technological value, cultural ones included. This happened for many reasons among which, on one hand, the opportunity that these companies can be established with a share capital as low as 1 euro, making this entity appealing for young entrepreneurs that generally haven't huge financial resources, and, on the other hand, for the great freedom granted to the private autonomy to conform the organization of this corporate type.

To be qualified as a cultural innovative start up, and consequently to be able to benefit from exemptions and fiscal measures laid down by the special legislation, it is necessary that these companies meet the requirements listed by Article 25, paragraph 2 of D.L. 179/2012, some of which must be satisfied concurrently while others are mutually exclusive. ${ }^{9}$ In detail, it is therefore necessary that the start ups: (a) have not shares or quotas listed on a regulated market nor on a multilateral negotiation system (Art. 25, paragraph 2); (b) have been operational for less than 60 months (Art. 25, paragraph 2, let. b) ${ }^{10}$; (c) must not be incorporated as a result of a demerger or merger or sale of business or division (note that the Ministerial Circular no. 16/E specified that the status of innovative start-up company is not denied as a result of business transformations and that any business combinations implemented by innovative start-up companies immediately after their incorporation will be evaluated by the tax authorities to ensure that they were not put into place solely to circumvent

\footnotetext{
${ }^{8}$ Despite there is awareness that most of enterprises are still today organized in the form partnership and individual enterprises, the aim of the legislator, confirmed by the discipline about innovative start-ups, is to steer and propel the business projects of small and medium enterprises towards limited liability company model, ie towards more advanced forms of companies but not too expensive, almost forgetting both partnership and individual enterprises and reserving the stock model to the realities of larger and more structured companies. See, in this regard, Cian, Le società start up innovative. Problemi definitori e tipologici, in AIDA, 2013, p. 425; Maltoni -Spada, L'impresa start up innovativa costituita in società a responsabilità limitata, cit., p. 2.

9 The Article 25, paragraph 2, of D.L. 179/2012 was amended by Article 9 of D.L.. 76/2013. See, in this regard Benazzo, op cit., p. 110.

10 The Article was amended by Article 4 of d.1. n 3/2015.
} 
such prohibition ${ }^{11}$ ) (art. 25, paragraph 2, let. g); (d) their principal place of business (PoEM) and centre of main interests must be in Italy (art. 25, paragraph 2, let. c); (e) starting from the second year of business, their total annual revenue per the latest financial statements approved within 6 months from the year-end must not exceed 5 million Euro; (f) must not have distributed profits since their incorporation year nor must they distribute any while the beneficial regime is in place. ${ }^{12}$

An additional requirement concerns their exclusive or prevalent corporate object, that must be "the development, production and commercialization of innovative products or services of high technological value" (according to art.

25, paragraph 2, let. f), D..L. 179/2012).

Without any doubt, the requirement about the corporate object is the most difficult to define because it has rather vague contours: indeed, neither is it easy to determine what are the innovative products or services of high technological value nor by whom and how the subsistence requirement should be assessed, given that the syntagma used by the special legislator has not a scientifically cerified content nor matches any pre-existing regulation.

From a careful analysis of the above-mentioned regulation, it seems that the adjective "innovative" must be considered together with the "high technological value", for the absence of any link that divides the two components. In others words, I believe that the expression used by the regulation must be read in the sense of considering that the corporate object of the innovative start ups, cultural ones included, must consist of development, production and commercialization of products and services qualified as innovative because they are characterized by high technological value. ${ }^{13}$ It follows that for a correct interpretation of the rule it is necessary to focus on the notion of high technological value.

First of all, it is interesting to note that the special legislation requires the presence of a high technological value and not of high technological content, thus focusing on the qualitative and not purely quantitative element.

The clarification is not insignificant, because also products and services characterized by low-technological content can meet the requirement as long as the technological component is inherently of high value, leaving unresolved doubts about the minimum level required and how to assess the presence of it.

\footnotetext{
11 This prohibition finds its rationale in order to to avoid abuse of the favorable prescribed discipline, avoiding that an existing company may form an innovative start up only transferring to itself for consideration or for merger or demerger a portion of its business complexit. It seems permissible, according to the interpretation of the provision in question made by Mise, with note prot. 01640298 October 2013, that also individual entrepreneur can access to the benefits provided for start-up innovative, giving life to a new company in the form of single-member company.

12 The rule prohibiting a five-year distribution of profits requires an obligation without exception to selffinancing, even if the company met its objectives. In licterature many authors believe too patronizing this attitude of the legislature.

13 The opinion in text contrasts with the view expressed by Cian, op. cit., p. 416, who believes that the activities of innovative start-ups should also be innovative and have a high technological content.
} 
Last, but not least, is the analysis of the adjective "technological". The definition of technology on the Treccani vocabulary says:

"Wide field of research [...], composed of different disciplines [...], which has as its object the application and the use of technical means in the broad sense [...], that is, all that can be applied to the solution of practical problems, to the optimization of the procedures, to the decision-making, to the choice of strategies aimed at certain targets. [...]it refers to the optimal use, also and above all from an economic point of view, of the set of different techniques and procedures used in a given sector, and of technical and more advanced scientific knowledge [...] and, more generally, to a set of theoretical and systematic elaborations, applicable across the planning and realization of productive intervention $[\ldots]$ ".

In this sense, and coherently with the purpose of the special legislation, it might be thought that the start-up activities could be aimed not only to the creation of new goods and services in absolute terms but also to the creation of good and services already marketed.

An additional degree of uncertainty still concerns the corporate object, whereas Article 25, paragraph 2, let. f), requires that it is exclusively or prevalently "the development, production and commercialization of innovative products or services of high technological value". The question is whether the innovative start-up activities can be constrained to one of the activities covered by the rule, and therefore consist in the conception and realization of a single industrial property, as well as in the mere marketing of products or services, albeit with a high technological value.

In this regard, I would prefer the negative solution, because the three activities set out in the rule-development, production and commercialization-are bound together by the conjunction "and" in place of the otherwise disjunctive "or".

The wording of the provision in exam suggests, therefore, that study, research and design are linked by a logical progression and each one represents just a phase that comprises the business activities carried out by innovative start-ups.

In my opinion, research and development can not be considered an exclusive activity, but rather an intermediate and prodromal step to the following implementation and marketing of innovative products or services. And again, a legitimate corporate object cannot be limited to the stage of commercialization of innovative products or services of high technological value.

In favor of this interpretation it militates also the fact that the predominant work force in a innovative start up structure must be made up of $\mathrm{PhDs}, \mathrm{PhD}$ students, researchers, which-should the contrary be true-would be required to work as mere resellers of products of high technological value.

However, what emerges with certainty from the special rule is that the innovative nature of the activity of a innovative start up, in order to allow access to the expected benefits, should be established at the outset, according to a prognostic evaluation. For this assessment, there is not an external verification: the existence of the requirement needed is self-certified by the legal representative.

Also, the rule also does not require that the planned activity be exercised exclusively; it is sufficient that it be prevalent. This means that the corporate object could 
be formed not only by technological innovative activities, but also by activities belonging to traditionally more mature sectors.

In addition, Article 25 requires the presence of one of these following conditions:

The first requirement concerns the quality of expenses incurred during the business activity. In particular, it is required that corporate costs can be attributed to $\mathrm{R} \& \mathrm{D}$ activities in measure equal to or greater than $15 \%$.

The second requirement provides that either at least $1 / 3$ of the total work force must be personnel with a Ph.D. or studying for a Ph.D. at an Italian or foreign University or with a university degree and certified three-year research experience at public or private research institutions, or 2/3 or more of the staff have a Master's Degree.

In the end, the rule requires that the innovative start up be the "owner (..) or licensee of at least one industrial property right in relation to an industrial or biotechnology invention or to topographies of semi-conductor products or the owner of the rights in a software registered with the special public software registry. ${ }^{14}$ Such property rights must directly related to the company's corporate objects and business".

As mentioned above, the innovative start ups to be qualified also as cultural innovative start ups must meet a further requirement: they must operate exclusively in the domain of cultural heritage promotion, as defined by the Code of Cultural Heritage and Landscape, ${ }^{15}$ and of cultural services provision, domain that the special legislation reserves to the innovative start up with social goals. It comes to start ups that apply the technological innovation to the activities of cultural heritage promotion and of cultural services research and provision, meaning the former as those activities aimed at promoting knowledge and dissemination of cultural heritage, at ensuring the best conditions of use, public use and conservation of cultural heritage; and the latter as the activities of cultural services research and provision as broadly defined, including both the so-called basic services, that are connected to the enterprise main activity, and the additional services, which contribute to the provision of basic services, offering to the user a plurality of performances that can facilitate the process of consumption, and the ancillary services, aimed at providing enhanced offerings.

From all of the foregoing, descends that the qualification of cultural innovative start up might be granted to a much more limited number of companies that can be called lato sensu cultural enterprises because for the exercised activity.

More precisely, the cultural and creative industries comprise a large and disparate group of economic realities: literary enterprises, publishing, music, theater, cinema, museums and the national artistic heritage, information technology, architecture, fashion and design. Cultural innovative companies are, within this large genus, a smaller species limited to those companies that apply technological innovation to the specific sectors of promotion of cultural goods and of provision of cultural services.

\footnotetext{
${ }^{14}$ On this point, it is important to stress that it is not clear the meaning of the phrase according to which "property rights must directly relate to the company's corporate objects and business": in particular, it is not clear if this ratio is to be understood in an instrumental or teleological sense. Furthermore, in D.L. 179/2012 miss any parameter for evaluating how the property rights must directly relate to the company's corporate or teleological sense. Indeed, the presence of such a requirement, like the others in Article 25 , is attested by the legal representative by means of its self-certification.

15 The Code of Cultural Heritage and Landscape was approved with Legislative decree January 22nd, 2004, no. 42 .
} 
As you can imagine, the entire chain of cultural heritage can benefit greatly from the introduction of innovative technologies. Not only-as is obvious-the scope of creative production, but also that of cultural heritage, which is based today from the point of view of the monitoring and the cataloguing, on the use of computers and new computing technologies, graphics, and storage, study and research. The innovative technologies are also helping for dissemination of artistic and cultural heritage, multiplying access both in qualitative and quantitative terms compared to traditional systems. ${ }^{16}$ Moreover, the application of new technologies is increasingly involved in museum activities: there are numerous museums that are acquiring applications for mobile devices (tablets, smartphones) to enrich the content of the visit for users. Through these applications, it is possible to intensify the experience in exhibition and museum scenarios, involving visitors in new experiences of enjoyment of cultural heritage and also approaching increasingly diverse audience segments.

Similarly affected by technological innovations are the libraries that implement their transformation by implementing digitalizing documents and allowing access through electronic channels, together with computerized tools for cataloguing and searching for information.

Given the above, the definition of cultural innovative start ups encompasse a wide variety of companies, including but not limited to those newly established firms that perform outreach activities and enhancement of cultural heritage by computer and multimedia communication tools (for example: 3D scanning, three-dimensional digitalization and interactive visualization, virtual reality, virtual reality for the blind people, automatic recognition of images, digital archival systems, software for automatic processing of texts in ancient languages and manuscripts, etc.); companies that perform diagnostic activities, conservation and restoration of cultural heritage (for example: measurement and monitoring of temperature and humidity, production and marketing of technology for the cleaning of works of art through biotechnology, etc.); again, companies that manage construction activities and museum services through new technologies, including additional services (lighting technology, virtual reality, multimedia compositions, virtual tours, reproductions and models, but also management of automated booking and ticketing).

\section{Equity crowdfunding}

The speciale legislation regarding the cultural innovative start up contained in D.L. $179 / 2012$ introduces also the discipline of the equity crowdfunding, an alternative financing method of corporate projects, that in recent times had a great development globally in any sector of the economy. It comes to a new phenomenon that has become of strategic importance specifically for smaller and strongly innovative

\footnotetext{
16 New technologies can help the cultural heritage to talk about hitself recontextualizing and providing, to those who had need, ability to study. One example is the recent initiative of the spectacle of the Ducal Palace in Urbino where four gallery spaces have been called to host multivisions of works of art contained in the Galleria with special sound effects: it is a path of images and comments meant for the understanding of the fundamental episodes of Renaissance culture of Urbino and Marche, with particular reference to the figure of Federico da Montefeltro, analyzed through the works of Piero della Francesca and the great painters of the Renaissance, until Raphael.
} 
enterprises, which have more difficulties to resort to traditional lenders as banks, business angels, venture capitalists, public administrations. This method actually obtains a great consensus precisely because it operates overcoming the traditional intermediators like banks and lenders. We're going through a time in which banks almost completely stopped lending, and there is a growing sense of distrust towards financial institutions, considered responsible for the economic crisis. On the other hand, venture capitalists and angel investors, whose presence is much more felt than in the past, keep supporting start-ups, but started asking for increasingly severer requirements and warranties.

More specifically, crowdfunding is a financing mode that involves a large number of people willing to invest money via Internet in business activity projects (including cultural and or social). The elements that differentiate crowdfunding from traditional channels to access credit can be identified, on one hand, in the prevailing participation of non-professional investors, and on the other hand, in the instrument chosen, i.e. the use of online platforms where demand and supply meet.

These platforms operate as a real intermediary supporting, on one hand, investors in the selection of the sectors and companies of interest and in the quick location of information about the project to be financed; on the other hand, start-ups in promoting their growth by encouraging contact with individuals interested in an investment.

In practice they are many different forms of crowdfunding: equity based crowdfunding, that consists in capital raising by an online platform, through the acquisition of a company's shares. The main feature of equity crowdfunding is that those who wants to sustain projects giving resources acquire a part of the capital stock. ${ }^{17}$ Donation-based crowdfunding-used generally for non-profit initiatives with philanthropic motives-does not provide refunds or returns neither in cash nor in kind to the partecipants ${ }^{18}$ in exchange for their contribution. Reward-based crowdfunding allows for capital raising by on line platform with a reward for a donation. Often the reward consists of a product made by the company with the funding ${ }^{19}$ received.

\footnotetext{
17 One of the fundamental characteristics of equity crowdfunding is that it finances not a single project, but rather an entire enterprises. The financing shall be in the form of acquisition of a portion of share or quotas. In fact, the equity crowdfunding allows in a stage of early development smaller investors to access the investment in a company. In exchange investors receive shares or quotas.

18 This is probably the most used and developed crowdfunding model. This type of crowdfunding founds entirely on people's donations, and do not give back any economical return for its supporters. This model is the most used by non-profit organizations and charities, which rely on patronage for their projects. Donation-based crowdfunding is also called "charity crowdfunding" just because is founded entirely on charitable donations. Donors give help because they share the values of the campaign and they want to give some type of support to particular action or idea.

In practice, the difference between donation b-----ased and reward-based crowdfunding can be can be hard to find, because in many projects there is the option for the lenders to give up a quid pro quo. Depending on whether a lender forgoes a quid pro quo, a project may therefore fall into the category of donation based or reward-based crowdfunding.

19 Through reward-based crowdfunding is possible ti financemany different projects, both no profit project and business projects. It is possible to finance also pojects in sport, cultur or social sectorsors. The compensatory measures may consist of simple symbolic objects or good produced with the money raised. For example, the creator of an innovative product can give the right to purchase it first, or at a lower price.
} 
Social lending crowdfunding - structurated in a similar way to the online microcredit - is the exchange of a certain amount of money given in the form of a loan, from a lender to a borrower using a crowdfunding platform. ${ }^{20}$

The choice about the type of crowdfunding depends to a significant extent both from the underlying project, and from the alternative to finance an entire enterprise or an individual business initiative, industrial, service-based or cultural.

The cultural and creative enterprises also show a growing familiarity with such financing and seem to prefer both the form of reward-based crowdfunding-when there is an interest on the part of donors for the final product or a creative project (i.e. creation of a CD, a movie) — and the form of equity crowdfunding, in which the lenders are made participants of the entrepreneurial initiative and thus of future gains realized by this.

In any case, whatever the type of crowdfunding chosen, it should be emphasized that this form of financing, having a participative character, promotes the interaction between an interested and committed audience and the promoters of a cultural business project, allowing interested parties to also broadly take part in the financing of culture, to actively support the development of a cultural project, and to be more aware of the context in which culture arises.

Italy, with d.1. 179/2012, became the first European country to implement a specific and comprehensive legislation on equity crowdfunding, ${ }^{21}$ which among the various types available is the one that most requires a specific legislation, because it promotes public offers involving the acquisition of shares or quotas, prompting the investor to make high risk illiquid investments. ${ }^{22}$ It is technically an investment solicitation regulated by the legislation of each country in relatively different ways which have a significant influence on the success of operations.

The critical issue which the Italian special discipline wants to address is the lack of channels to access funding for newly established business entities, characterized by a high mortality rate but also by the possibility of generating high returns should their business be successful, especially in relation to initiatives based on innovative products and technologies. Because traditional intermediaries, indeed, often have no

\footnotetext{
${ }^{20}$ Lending- based crowdfunding is the exchange of a certain amount of money given in the form of a loan using a crowdfunding platform. The lender publishes the request on a platform, asking for a precise amount of money, and when they raise enough money, the platforms originates the loan and paid it to the borrower. Usually (but not always) the petitioner pays an interest on the debt. The set interest rate is usually higher than the average saving rate a lender can have, and lower respect to that of a traditional loan, for the borrower.

21 Italy was the first country to issue a specific regulation for equity crowdfunding, and this discipline, in our country seems very lively, notwithstanding the difficulties in providing financial resources. The European Commission itself has never hidden its interest for this form of funding that was defined as "fundamental". The E.C. goal is to promote a harmonisation of European legislations, to overpass the limits encountered by platforms that want to operate abroad. The reasons are that is helpful not only in crisis periods, but also to create an "alternative banking system", overcoming

the limits of traditional banking processes.

22 Equity based crowdfunding consists in capital raising by an online pltform, through the acquisition of a company's shares. The users of this model are those who wants to sustain projects giving resources to acquire a part of the capital stock. The funders became stockholders of the society, so it is easy to understand how this is the model with the highest percentage of risk.
} 
incentive to direct loans to such risky forms of investment, mainly because of constraints and more stringent rules than in the past, crowdfunding could be an important solution, as it offers alternative means of promoting business initiatives, directly aimed at savers-investors, which also helps to reduce intermediation costs.

Furthermore, crowdfunding, by using the web, allows greater visibility to startups and more widespread capillarity in the audience, useful for the funding of impact and innovative projects as it translates into a higher chance of membership from investors,.

One of the most effective novelties of the special legislation is represented by the provision of equity crowdfunding for all the innovative start ups regardless both of the activity exercised and-more important—of the chosen legal form. In particular, with regards to the limited liability company (s.r.1.), the D.L 179/2012 prescribes an express derogation from the provisions of Article 2468 of civil code, on the basis of which "the partecipation of partners can not be represented by shares nor constitute object of public offerings of financial products".

Article 25, paragraph 5, of D.L. 179/2012, indeed, prescribes that "the partecipation quotas in innovative start ups incorporated in the form of limited liability company can be object of public offerings of financial products", specifying that such assistance could take place also "through on line portals for the raising of capital".

Beyond the civil law exception, the D.L.179/2012 had a significant impact, as well as on the statutory regulations, also on elements related to purely financial aspects, revising the Legislative Decree 58/1998 to regulate the raising of capital through special online portals.

The subsequent intervention of D.L. 3/2015, in addition to expanding the scope of application of the crowdfunding discipline, allowed to sell online not only fractions of capital belonging to innovative start ups, but also to specialized investment vehicles (OICR, Venture capital), whose main asset is represented by investments in start-ups and innovative SMEs.

The participation in a crowdfunding campaign means for the saver-investor to acquire a part of the capital stock of the offeree company, namely risk capital instruments, thus becoming shareholder and owner of the connected corporate rights. 
Based on the approach used by the Italian legislator, indeed, the equity crowdfunding campaigns are configured as paid capital increases. ${ }^{23}$

This means that, following the success of the operation, the investor can participate in corporate affairs by exercising the statutory rights, such as the voting rights exercisable at shareholders' meeting, the right of approving the financial statements and, in case of profits, the right to receive dividends.

The various rounds of financing are all single divisible paid capital increases, thus allowing the share capital to be be increased by an amount corresponding to the subscriptions collected.

As it is not possible to know in advance the outcome of the collection, the contribution already made by the crowders could be considered such as payments for future share capital increases. Especially in case of resourses acquired from third parties rather than by existing shareholders, this solution seems more appropriate, primarily because for those capital injections the company has a repayment obligation in case of non-completion of the process: the payments made in anticipation of a specific future share capital increase shall be considered subject to the condition subsequent to the fact that the deal execution is not completed in the way and by the deadlines proposed by the company.

Consequently, the presence of a condition precedent imposes the initial allocation of such sums as debt: depending on the outcome of the operation, the amounts will be consolidated under the heading "equity" or, otherwise, as debt (because in such instance the subscriber has a right to reimbursement).

Since the offer may also fail, third parties do not assume member status immediately after the subscription and consequent payment, but only when the operation is closed and the decision about the capital increase recorded in the Companies Register.

For the offer to be completed, it is necessary that at least $5 \%$ of all financial instruments offered be subscribed by professionals investors or by other special categories of investors (such as foundations, incubators, investors supporting innovation, professionals_-public and private_clients). These investors, for their professionalism

\footnotetext{
23 The crowdfunding phenomenon is a reality that cannot be ignored: the rapid growth and spread, in a historical moment characterized by the increasingly tight credit of the traditional financing channels has enabled a relevant and intensive development beyond a volume of five billion dollars. The equity crowdfunfding statement as a credible and reliable instrument on the market as an alternative financing poses the conditions for a change of broader global economical breath. The potentialities of a tool, that if properly structured could represent a revolution in the processes involved in setting up a business, are evident. The validity of a project's company no longer needs the consent of a bank or financial institution and the "power" to declare the development of a business venture will not be a monopoly, in the hands of the great financial masters of the world. Thus with crowdfunding there is a democratization of the economy, meant as the possibility to easily access the capital needed for businesses, but also as users' freedom of access different investment opportunities. A system in which merit is the true source of success and where the application and innovation can rise to real drivers of the engine. As a result this model could develop a greater maturity of the entrepreneurial class that will have to pay greater attention to the market needs and to prove more sensitive in terms of transparency. Surely we cannot expect crowdfunding to conceive these mechanisms in the near future and certainly will not supplant the essential activities of traditional financial markets, but the feeling is that it can actually be a form of innovation that can rejuvenate the way of doing business and can adapt the concept of the era of the entrepreneur world-wide-web.
} 
and characteristics, were considered by the legislator as trustworthy entities, whose participation in the issuer's share capital and whose evaluation about the operation can represent a further guarantee for the other investors. The 5\% threshold above mentioned is a condition of effectiveness of the offer. Therefore, in the event that the threshold is not reached, the crowdfunding campaign will not be completed.

\section{Investors' special rights in cultural innovative start-ups}

Since, as mentioned above, the highest number of innovative start ups, even cultural, chose to be incorporated in the form of limited liability company (s.r.l.), the provision contained in Article 26, paragraph 2, of D.L. 179/2012 is extremely interesting. The reason for this is that it allows the possibility for the statute of innovative startups in the form of limited liability company to create classes of quotas conferring different rights and, within the limits imposed by law, to freely determine the contents of the various classes, even in derogation from the provisions of Article 2468, paragraphes 2 and 3, c.c..

It is a legislative provision of extreme importance which makes it possible for the cultural start ups in form of limited liability company to issue quotas with special rights, different from those pursued by common discipline, that can be applied also to fields other than the administration of the company and of the profit distribution.

It is also expressly regulates the possibility of creating multiple kinds of unitary, standardized, indivisible and cumulable quotas in the hands of the same shareholder, bearing uniform rights other than those covered by the ordinary regime.

These regulatory provisions are consistent with the possibility of soliciting investments and of obtaining risk capital among the public for quotas of innovative start ups in form of limited liability company, also through on line portals.

In fact, the provisions mentioned allow the start up to tailor equity participation to the needs of different categories of owners, setting up different roles among owners and facilitating the research of financing in risk capital.

With respect to limited liability company trying to raise capital by crowdfounding, the options offered by the special legislation allow the company on one hand to consolidate the position of the founding quotaholders, possibly giving them special personal rights concerning the management of the company or the election of Directors and, on the other hand, to create also additional categories of quotas with different rights, most suited to need of investors, exclusively interested in the economic return of their investiment and not in the management of the company.

In the same sense, given that the Consob Regulation no. 18592, as last amended, subjects the success of the offer on the on line portals to the condition that $5 \%$ or more of the subscriptions happen by professional investors (such as banking foundations, start ups incubators, investors supporting innovation) the rules above mentioned allow also to fine-tune the content of these partecipations according to the interests and characteristics of these investors, which are certainly interested in the economic return of the investment without willing to sacrifice the right to have a say in the management of the company. 
It is important to remind that, unlike in the spa, the categorization of limited liability company quotas may be also partial, and concern only that part of the quota capital dedicated to crowdfunders and/or professional investors.

As emphasised by literature, no regulation prevents a start-up with limited liability to insert in the statute a clause enabling the categorization of only a part of the quotas. In this case, both standardized quotas and ordinary quotas may coexist in the same company, as well as special rights attributed directly to individual members and categories of quotas with different rights.

As for the content of the various classes of quotas, the paragraph 2, Article 26 of D.L. 179/2012, according to which the start up may freely determine the content of variouos classes of quotas, within the limits imposed by law, suggests that the start up in form of limited liability company has wide discretion in determining the content of the rights attached to them. More precisely, this means that the statute may impact both on economic and administrative rights, allowing the modification of both also simultaneously.

Along the same lines is the provision in the following paragraph 3 of art. 26 of D.L. 179/2012 which provides that the Statute of the innovative limited liability company may create also classes of quotas without voting rights or that attributes to the owner voting rights not proportional to its participation to the capital or voting rights limited to particular matters or subject to the satisfaction of conditions not merely potestative.

The rule above mentioned assimilates the structure of the limited liability company to that of the joint-stock company.

The quotas without voting rights or with limited voting rights are tailored to subjects interested just in the economic aspect of their investment, whose presence does not compromise the sovereignty of quotaholders that are involved in the management of the company. The owner of this quotas is comparable to the owner of savings shares in the joint-stock company, physiologically uninterested in the exercise of administrative rights connected to the partecipation.

In contrast, the possibility to issue multiple-vote quotas allows to meet the needs of quotaholders more interested to make their voice heard, such as venture capitalist or the innovative start ups incubators or, alternatively, to allow founders to retain control of key aspects of the management of the company while raising funds that could potentially dilute their grip on such aspects.

\section{Innovative cultural startup incubators}

The creation of a regulatory framework and an ecosystem favourable to the birth and growth of so-called innovative cultural startups also involves the provision of certified incubators, meaning by this the enterprises which "offer, including on a non-exclusive basis, services to sustain the birth and growth of innovative startups" and which are in possession of the requisites indicated by Article 5 of the Decree of the Italian Ministry of Economic Development dated 21 February 2013 (so-called Incubators Decree). 
The purpose of these incubators is to accommodate, support and accompany the growth of the innovative startups from the conception of the entrepreneurial idea through to initial development, providing training activities, operating and managerial support, work tools and places and favour contact between investors and entrepreneurial ideas thought to have strong potential in terms of economic return, but not yet appealing for the capital market. ${ }^{24}$ This way, the certified incubators enable the innovative enterprises to launch their businesses onto the market effectively and above all quickly. For the services they provide, the incubators are remunerated in various ways, through the consideration paid by the incubated companies, so-called fees, i.e., shares of corporate capital in return for investments in risk capital or, again, a combination of both models.

It must be emphasized that the carrying on, including in a professional and systematic way, of innovative startup incubation activities does not represent an activity restricted to so-called certified incubators and can, therefore, be performed by any entity, public or private. In fact, the certification of the incubator is simply a condition for registration in the relative section of the Companies Register and to access corporate and tax subsidies.

In the system outlined by D.L. 179/2012, only incubators established as corporations, cooperatives or societas europaea, fiscally resident in Italy pursuant to Article 73 of Presidential Decree 917/1986, can register in the special section. On the other hand, companies set up under the laws of another country cannot register. Now, while the prohibition in effect with respect to companies set up under the laws of a non-community state does not seem to create particular perplexities, the same is not true instead with reference to the provision which does not allow the incubators set up according to the laws of a member state of the European Union and which have set up a sub-office in Italy to register in the special section.

This is in fact a provision which, from the point of view of community law, appears to be strongly discriminatory with respect to community incubators, probably supplementing an illegitimate restriction of the freedom of establishment guaranteed by Articles 49 and 54 of the Treaty on the Functioning of the

\footnotetext{
${ }^{24}$ The physical concentration of these new enterprises in these spaces favours encounter and discussion between the various startuppers allowed into the incubator and fosters an extensive exchange of knowhow. The organisation of these systems is based on the interception of the real needs of the startups in order to make the startup phase less complex and increase chances of success. The incubators must therefore be clearly aware of the life cycle and supply chain for the birth and growth of the innovative startups. This means that structural services must be placed at the disposal of the startups, such as spaces and facilities able to accommodate the startups, equipped premises, optical fibre cable installations, meeting rooms and auditoriums. Adequate spaces in themselves are not however enough to sustain the enterprise. Qualified services are required to provide the new class of entrepreneurs with advanced training together with coordinated promotion and marketing initiatives, shared databases, common projects and integrated agreements with the credit system, or for the use of special laboratories and technological platforms. In order for the incubation activity to be successfully conducted, other characteristics are also needed such as the presence of start-ups in the organizations, an indication of already acquired experience, and the start of collaboration with various entities, which can be of both a public and a private nature, e.g., universities, local authorities, banks, chambers of commerce, venture capital and business angel networks, corporates e other already-launched startups. It must be shown that an effective ecosystem has been created which surrounds the startups and offers greater possibilities during the various development phases.
} 
European Union, as interpreted by the Court of Justice in Centros, Uberseering, Inspire Art, Sevic, Cartesio jurisprudence.

It must therefore be considered that the Companies Register could not deny registration in the special section to an incubator set up according to the law of another Country of the European Union which has set up a sub-office in Italy.

The status of certified incubator is acquired through the registration of the incubator in the special section of the Companies Register. Such qualification not only brings with it a reputational advantage for the incubator but also the application of special regulations and numerous benefits, substantially corresponding to those provided for innovative startups, with the basic difference that such benefits do not have a limited duration, but continue to be applied until the incubator has all the requisites required by law.

To obtain the status of certified incubator, the company must have all the following requisites together:

(a) have facilities, including immovable, suitable for accommodating innovative startups, such as dedicated spaces for installing test, auditing or research equipment;

(b) have equipment suitable for the business activity of the innovative startups, such as Internet access systems, meeting rooms, test machinery or prototypes;

(c) be managed or directed by people of acknowledged expertise in enterprise and innovation and have a permanent technical and managerial consultancy organisation;

(d) have regular relations of collaboration with universities, research centres, public institutions and financial partners which perform business activities and projects related to innovative startups;

(e) have adequate and proven experience as regards support activities for innovative startups.

The first two requisites are of a structural nature, while those at the letters (c) and (e) focus on manager duties. The requisite at let. (d), furthermore, calls for the demonstration of a network of contacts with stakeholder as a crucial condition for building an eco-system suitable for the birth and growth of the innovative startups.

The Incubators Decree also specifies, as regards requisites, that a certified innovative startup incubator can provide services in support of startups "also on a non-exclusive basis". This same decree also puts in-depth focus on the requisite of the experience of whoever manages the incubator and specifies that this must be identified "in the shareholders, in the directors of the company and in the work units, collaborators or professional persons who work with continuity, equivalent to full time (FTE)" in activities "specifically dedicated to the support and advisory services to innovative startups".

Since the coming into effect of D.L. 179/2012 to date, even though-as has already been said- such provision does not allow so-called certified incubators to perform innovative startup incubation, including in a professional and systematic way, the number of incubators operating in Italy has considerably increased. 
In practice, innovative startup incubators show a very determinate specialization in terms of subject matter and geographic area. The reason for this seems to be rather easy to appreciate, considering the incubator must not only have adequate structural capacities, but also a managerial skill in the specific activity performed by the innovative startup as well as a network of contacts with stakeholders of specific usefulness for the incubated enterprises.

On the Italian scene, over recent years, the number of cultural incubators has grown considerably, i.e., those incubators which assist the birth and growth of cultural and creative enterprises, of artistic and design incubators, as well as enterprises which apply technological innovation to cultural assets. ${ }^{25}$ Mention is made, by way of example, of the experiences of Artimede, \#SMART, CultLab, Rioni Sassi, Herion.

Many of these incubators are public bodies, i.e., business entities established and owned by local public entities (councils, provinces, regions) and/or universities, and therefore not profit-oriented. Such types of incubators provide their services at lower prices than those of the market, and even in some case free of charge, and access to their services is also by means of public notices. Many examples nevertheless exist of private-entity incubators focused on enterprises of social and/or cultural value and which manage to achieve an economic equilibrium of their own (Make a Cube).

\section{Exceptions to crisis law}

The special law on innovative startups indicates a number of major exceptions to common law on the reduction of corporate capital due to losses, both with reference to the case of losses of over one-third, and in relation to a loss of over the minimum (art. 261 leg. decree 179/2012) and loss making companies (art. 31, paragraph 1, D.L. 179/2012), even though these rules are intended to be applied for limited periods of time, like all special rules regarding innovative startups.

With reference to losses above one-third of the capital, Article 26, sub-section 1, of the decree Crescita bis establishes that for innovative startups the term within which the loss shall have dropped to less than one-third is postponed to the second subsequent business period, i.e., one year with respect to the ordinary term set by Articles 2446, sub-section 2, Italian civil code and 2482 bis, sub-section 4 , Italian civil code. Furthermore, in case of a loss that reduces the capital to below the minimum, the shareholders' meeting, promptly convened by the directors, can, as an alternative to the immediate reduction of the share capital and the simultaneous increase above the minimum, decide to postpone such decision until the closing of the subsequent business period, without the company being wound up due to reduction or loss of share capital. If the capital has not been

\footnotetext{
${ }^{25}$ Cultural innovative startups, like any other cultural and creative enterprise, in most cases consist of entrepreneurs and persons with professional backgrounds which differ considerably from the managerial approach and because of this, perhaps more than other categories of enterprises, they require the support of incubators.
} 
reintegrated above the legal minimum by the subsequent business period, the shareholders' meeting which approves the financial statements of such business period shall, alternatively, reduce and increase the capital to at least the minimum or transform the company or wind it up.

Time deferment in case of reintegration of equity or recapitalization represents a concession which the legislator makes with respect to an innovative startup, for the purpose of giving it time enough to minimize the initial losses determined, it is thought, not so much because of a situation of sufferance of the economic initiative undertaken, rather than because of the weight of the debt in the initial stage of the business activity. Innovative enterprises, above all in an initial stage which the legislator quantifies in five years from setup, may have to make heavy investments which have an effect on net equity. This is undoubtedly a rule which privileges the arguments of the shareholders compared to those of company creditors, enabling the company to continue operating despite losses, with the concrete risk of the financial difficulties becoming worse. It nevertheless finds a precise justification, in a perspective of policy of law, in the positive consequences in terms of public well-being and economic growth for the market as a whole and for the public in general deriving from the carrying out of an economic activity centred on the production of innovative assets and services. In other words, the innovative startup enterprise is obliged to manufacture and market innovative products and services of high technological value, which can present a higher rate of intrinsic risk due to the possible non-viability of the products being developed or to their lack of market success. Consistent therefore with the benefit which the market and the public can derive from it is the exception to those rules which impose a minimum level of financial stability.

In the same vein is the legislation provided in case of a crisis by art. 31, subsection 1 , of decree $179 / 2012$, which permits extending to innovative start-ups the benefit of the legislation for managing an over-indebtedness crisis, provided by law 3/2012. For the entire period during which such enterprises maintain the qualification of innovative start-ups, irrespective of the type of business activity performed or of the exceeding of the dimensional limits indicated in Article 1 of the bankruptcy law, none of the bankruptcy procedures shall apply to such enterprises indicated in R.D. no. 267 dated 16 March 1942: institutions do not therefore apply such as bankruptcy, arrangement with creditors and administrative compulsory liquidation.

Consequently, those innovative start-ups which are in a state of "lasting instability between obligations assumed and readily redeemable assets to address them, which determines the considerable difficulty of fulfilling their obligations" or "the definitive inability to fulfil them regularly", can present their creditors with a debt restructuring agreement or, alternatively, the liquidation of the equity.

The reasons at the bottom of such decision can be traced back to the fact that whosoever decides to go into business and invest in activities with a high level of innovation shoulders a greater economic risk compared to the rest of the market. The special legislator intends offering such entrepreneurs the chance to benefit from a simplified procedure compared to that provided by R.D. no. 267 dated 16 March 1942, which cuts the liquidation times of startups in crisis and reduces the 
involvement of the judge to marginal aspects of the procedure, and at the same time limits the negative effects of same tied to a bankruptcy sentence, enabling it to start again with a new and different business project (fresh start). Worded in this sense is the illustrative Report to D.L. 179/2012, the Article 25 of which carefully points out how being subject to a simplified liquidation procedure helps encourage many new potential entrepreneurs to start an innovative startup, and to change the prevalent culture which still sees the lack of achievement of a business idea as a failure rather than an accumulation of experience.

Funding Open access funding provided by Alma Mater Studiorum - Università di Bologna within the CRUI-CARE Agreement.

Open Access This article is licensed under a Creative Commons Attribution 4.0 International License, which permits use, sharing, adaptation, distribution and reproduction in any medium or format, as long as you give appropriate credit to the original author(s) and the source, provide a link to the Creative Commons licence, and indicate if changes were made. The images or other third party material in this article are included in the article's Creative Commons licence, unless indicated otherwise in a credit line to the material. If material is not included in the article's Creative Commons licence and your intended use is not permitted by statutory regulation or exceeds the permitted use, you will need to obtain permission directly from the copyright holder. To view a copy of this licence, visit http://creativecommons.org/licen ses/by/4.0/. 